ARTICLE

DOI: $10.1057 /$ s41599-018-0068-x

\title{
Slums, race and mental health in New York (1938-1965)
}

\author{
Dennis Doyle ${ }^{1}$
}

\begin{abstract}
Claude Brown's seminal 1965 memoir "Manchild in the Promised Land" appeared when Americans were trying to make sense of the Watts Rebellion of 1965. A "bildungsroman", Brown's autobiography details how he, a former juvenile delinquent and residential treatment center client, became a stable adult once he left his troubled Harlem neighborhood. This paper argues that Brown's book revealed just how much liberal midtwentieth century efforts to combat poverty and crime in segregated black communities by offering more mental health services struggled to fully grasp and address the relationship between mental health and environment. Between 1938 and 1965, officials and mental health experts with the Wiltwyck School for Boys, New York Domestic Relations Court and the New York Bureau of Child Guidance imagined that Harlem would become a more stable, lawabiding community if populated with emotionally healthier people. Methodologically, this paper compares the archival record of those programs' goals with Brown's memoir. Brown's own experience as both a former charge of those institutions and a resident of Harlem led him to doubt that urban ghettoes were environmentally suited to support individuals struggling to overcome mental illness. In locating Brown's recollection of his postwar youth within the context of local efforts to provide New York City's black juvenile delinquents with psychiatric care in the postwar era, it becomes apparent that those liberal policies and programs were designed to produce therapeutic outcomes that proved difficult to sustain amid the challenging circumstances residents faced in socioeconomically depressed communities. As an intervention into the burgeoning literature on the US history of race and psychiatry, this research represents one of the first attempts to compare the intentions of mental health professionals seeking to improve the health care of African Americans and the perspectives of their African American clients.
\end{abstract}

\footnotetext{
${ }^{1}$ St. Louis College of Pharmacy, St. Louis, MO, USA. Correspondence and requests for materials should be addressed to D.D. (email: dennis.doyle@stlcop.edu)
} 


\section{Introduction}

n 1965, African American law student Claude Brown published his controversial autobiography, "Manchild in the Promised Land". In this "bildungsroman", the first-time author recounts how he was able to escape a life of petty crime and drug dealing in Central Harlem. 1965 was a crucial year in the black freedom struggle. Integrationists won a major victory with the Voting Right Act but the black power movement lost an icon when El-Hajj Malik El-Shabazz (Malcolm X) was assassinated in February. Released the year of his death, "The Autobiography of Malcolm X", joined Brown's memoir, psychologist Kenneth B. Clark's "Dark Ghetto", and the Moynihan Report as new books white America hoped would unlock the mystery of black urban life. Brown's was a bestseller, attracting more than its share of criticism, controversy, publicity, and scholarly analysis (Brown, 1965; Karolides et al., 1999, pp 389-392). Some reviewers regarded Brown as an expert on black America, providing an insider's view on the so-called "urban crisis"-the economic decline of US cities, particularly in its predominantly black slums (Rotella, 1998).

On August 30, 1965, "Commentary's" neoconservative editor Norman Podhoretz engaged in a televised conversation with author Claude Brown on the National Education Television program "At Issue". Podhoretz asked him for his opinion of the Watts Rebellion (or Riot). Just over 2 weeks earlier, the Watts neighborhood of Los Angeles, California had been hit by a spontaneous uprising led by its predominantly black residents. Property was destroyed, thirty-four people died, and fires set before the National Guard was called in to halt this mass resistance against a recent act of police brutality. Brown answered: "The riots are a good thing...they had the best idea in Los Angeles that anybody's had about any of the ghettoes yet. Burn it to the ground." Shocked and incredulous, Podhoretz next asked: "Would you like Harlem burned to the ground?" To which Brown responded: "It would be great idea" (Podhoretz and Brown, 1965, p 20).

Brown's call for Harlem's destruction shocked the "law and order" sensibilities of the neocon Podhoretz, but they also posed a challenge to racial liberals who had been trying to save Harlemites -including Brown--for the past thirty years. In New York, racial liberals - an interracial cadre of individuals who shared the political aim of ending racial inequality by equally including African Americans within the state--had called for programs to revitalize Harlem by expanding the black community's access to public mental health resources. Regarding mental health services, racial liberals in the Domestic Relations Court, Bureau of Child Guidance, and the private Wiltwyck School for Boys had long recommended saturating those neighborhoods with psychiatric care. Such plans called for the city to improve Harlem's access to services that could help alleviate the suffering of marginalized people with a range of psychological or behavioral issues that contemporary experts referred to using the interchangeable terms emotional illness and mental illness, remaking public health in Manhattan's most overcrowded living space.

Yet here was Brown, a former client of racial liberals at the Wiltwyck School, advocating that such liberal efforts to include Harlem in the nation's prosperity ought to be scrapped. Harlem did not need inclusion. It required destruction, demolition, obliteration. What he was demanding was true slum clearance: an end to ghettoes. This paper offers that Brown's off-the-cuff apocalyptic solution to the urban crisis in his televised encounter with Podhoretz, when viewed in the context of his "Manchild in the Promised Land", demonstrates an impatience and distrust with liberal efforts to save or improve the so-called ghetto. When put into conversation with his televised remarks, Brown's 1965 memoir demonstrates a thinker with a unique insight into the limitations of racial liberalism, especially efforts to ameliorate the plight of Harlem through the expansion of mental health care within the black community.

In this paper I argue that Brown believed such efforts were doomed to failure in segregated black living spaces because those places were not conducive to mental health. In his autobiography Brown recognized that emotional health was not something one achieved in isolation. Instead it was something that could not exist without amenities, good jobs, public resources, decent schools, economic stability, and medical care. While racial liberals sought to provide more mental health care to Harlem as a way to promote mental health amongst its African American residents, Brown's life experience had taught him that the services that he had encountered-in the courts and at the Wiltwyck Schoolhad not generated the results his liberal benefactors had expected. For Brown, the ghetto was not salubrious enough to sustain the kind of individual therapeutic changes racial liberals sought to make with black patients through the schools, courts, or Wiltwyck School's Manhattan halfway house.

This historical examination of midcentury crime prevention and mental care expansion in Harlem intervenes in two historiographies: psychology and its relationship to the urban crisis, and psychiatry and its engagement with African Americans. The work of Ellen Herman (1995), Michael E. Staub (2011), Brian Tochterman (2017), and Ed Ramsden and Matthew Smith (2017) have traced the rise of the widespread nostrum that the economic decline of cities caused mental deterioration. Although the idea that slum life could harm a resident's internal life had Victorian precedents, it caught fire in US social science and politics after World War II with the rise of social psychiatry-a preventive psychological paradigm that asserted a relationship between mental health and environment-and the use of psychology in framing urban crime, blight, poverty, slum clearance, and riots within policy circles (Smith, 2016). This article engages with that literature at a historiographical intersection with scholarship on the role race played in debates over the urban crisis's psychological impact. The work of Daryl Michael Scott (1997), Ellen Dwyer (2005), Jonathan Metzl (2009), Jay Garcia (2012), Mical Raz (2013), Martin Summers (2014), and Gabriel Mendes (2015) have shown that, since at least the 1930s, anti-racists and liberals claimed that Jim Crow and segregation had emotionally harmed blacks. This article tries to bring together these literatures on the urban crisis and the black psyche, exploring the policies and assumptions of the liberal psychiatrists, judges, and social workers who interpreted the wartime rise of youth crime in Harlem as the result of both the mental health dangers posed by slum life and racial inequality in the distribution of mental health resources.

What follows is a comparison of liberal campaigns against both youth crime and mental health disparities in Harlem between World War II and 1965 and Brown's own experience as one of the very Harlemites those racial liberals had served. The paper will examine each of these programs and their intended goals, contrasting them with Brown's insistence that Harlem's psychological health would be difficult to redeem as long as Harlem remained virtually unchanged. The first section of the paper draws upon Foucauldian political theory to briefly examines both the aims of these liberal programs and their assumption that therapy could overcome the psychological impact of Harlem slum life. Since World War II, New York's racial liberals in child psychiatry, child guidance, and the children's courts assumed that slums-especially in the guise of the strain it allegedly placed on family dynamics - led to an inordinate amount of emotional and behavioral problems among its youth. These liberal New Yorkers believed that institutional racism had prevented authorities from providing Harlem's emotionally ill children with the mental 
health care needed to help them develop the self-control expected of citizens. They imagined that Harlem's disruptive classrooms and youth crime or "juvenile delinquency" would decline once Harlem's streets teemed with people who had received psychiatric care. Relying on archival evidence and policy reports, the next two sections examine how this faith in psychiatry's power to prevent crime and treat psychological suffering in Harlem produced three programs (the Harlem Special Guidance Service Unit, Joint Kindergarten Project, and Harlem Project) that concentrated therapeutic and preventive services in Harlem schools between 1940 and 1945. The fourth section explores how many of the same racial liberals also sought to neutralize Harlem's mental health risks for black youth offenders-including Brown-by placing them with the Catskills' Wiltwyck School for Boys and its aftercare facilities.

The fourth and fifth sections also feature a close reading of the passages in Brown's memoir regarding his experience as a former client of the liberal Wiltwyck School and his psychological insights into psychiatry's limited usefulness in Harlem. I aim to demonstrate that Brown, as a Harlem resident, was able to recognize and challenge the faulty assumption underwriting racial liberals' hopes for mental health care's expansion in Harlem: namely, that mental health could proliferate there without major changes to Harlem as a living space. Brown believed that his own emotional health only improved once he left Central Harlem, observing that those who remained behind seemed at higher risk for seemingly interminable drug addictions and behavioral problems. In teasing out Brown's own ontological assumptions from his memoir and unpacking them using the insights of philosopher Ian Hacking, this paper makes the case that Brown was able to question that flawed core assumption informing liberal mental health programs in Harlem because he recognized that Harlem lacked the environmental supports needed to sustain the self-regulating mode of subjectivity that both modern psychology and racial liberalism promoted. By making a Harlem patient's own perspective on mental health and the environment central to the history of racial liberalism and the psychological sciences in Harlem we can more clearly understand why, in his TV interview, Brown rejected efforts to salvage Harlem in favor of burning it to the ground.

\section{Eliminating racial slippage in productive power: New York liberals and the fight against juvenile delinquency, 1940-1945}

In the New York City of Mayor Fiorello La Guardia, juvenile delinquency in Harlem had become a major source of concern entering World War II. Juvenile delinquency was a contemporary label for violent or criminal child behavior that usually resulted in an arrest and a court hearing. In New York, the majority of children remanded to the Children's Court on charges of juvenile delinquency were African Americans from Harlem. Liberal judges, psychiatrists, psychologists, and their allies in the local civil rights movement made the argument that crime and juvenile delinquency had increased because La Guardia had provided Harlem with few crime prevention resources-even after the Harlem Riot of 1935 (Markowitz, Rosner, 2000, pp 5-12). According to Khalil Gibran Muhammad (2010, pp 3-9, pp 152-154), critics in New York and other cities blamed institutional racism for the lack of crime prevention tools in segregated black communities. Since the 1920s, child guidance, mental hygiene, and psychiatric social work were considered the latest and most scientific ways to fight juvenile delinquency. Each of these disciplines framed juvenile delinquency as the product of a previously undiagnosed psychological issue. Previously, most Victorian Era criminal justice officials had long understood juvenile delinquency as willful misbehavior that could only cease with harsh punishment. But with the psychological turn, a juvenile delinquent became an emotionally needy child whose habitual misbehavior might cease with psychotherapy and psychiatric case work (Jones, 1999; Horn, 1989). Liberals pressed La Guardia to spread those services into Harlem.

In Foucauldian terms, liberals were asking for the extension of a more productive system of power to Harlem's African Americans. Power is productive when cultivated through the collective self-management of the masses. Some conspiracy or single ruling authority does not generate this diffuse type of power. Instead, it develops through the efforts of private and public authorities, all separately working to help citizens internalize societal norms and regulate their own personal conduct. ${ }^{1}$

In limiting black access to psychiatry, institutional racism prevented productive power from being fully extended into Harlem on a more racially equal basis. According to anthropologist Rosalind Morris (2008, p 110), the techniques for generating such productive power have been "unevenly distributed among people of different racial categories" since the Progressive Era in both European empires and the United States. This longstanding institutional neglect of black subjectivity was predicated by the assumption that non-whites were incapable of the self-regulation expected of normal, law-abiding Americans. From a racial conservative's standpoint, it made little sense to provide African Americans with an opportunity they were racially incapable of using (Muhammad, 2010, pp 3-9, pp 152-154).

In contrast, racial liberalism was animated by the faith that productive power could be generated in and through black minds and bodies. New York liberals and racial progressives such as Children's Court Judges Justine Wise Polier and Jane Bolin were convinced that African Americans were capable of introspection and emotional self-management. These racial liberals-whose ranks included both African Americans and whites--saw the modern liberal state's lack of investment in African-American mental health not only as an unjust act of misrecognition but as a major oversight (Ward, 2012; Doyle, 2016). According to historian Ellen Herman, the kind of "therapeutic government" (Herman, 2008, p 11, pp 12-13, p 206, pp 285-286) that Polier and other racial liberals promoted was supposed to reduce social problems through more invasive management/reduction of pathological behaviors and unhealthy emotional states (Stoler, 2009, p 3). Perhaps with more psychiatric care in Harlem, its crowded streets would suddenly teem with individuals emotionally stable enough to avoid the temptation of gangs and crime.

Between 1940 and 1945, racial liberals in New York's Bureau of Child Guidance, the Domestic Relations Court, and its School of Social Work created several public school programs for Harlem intended to identify, treat, and track African American children thought to be at greatest risk for the emotional illnesses that caused juvenile delinquency. Judge Polier convinced the New York City Board of Education to implement these new programs, arguing that removing racial barriers to a more equal distribution of psychiatric services would enable the modern state to more effectively establish productive power through the personal lives of Harlem's black citizens, especially during the critical patternforming years of childhood. According to Polier, this wartime extension of psychiatric authority over the lives of black students in New York's public school system would increase mental health in Harlem and ultimately diminish the "rate of court appearances and institutional commitment" in Harlem (Polier, 1940).

\section{Developing the productive power of P.S. 194: the joint kindergarten project}

This increased public investment in black Harlem's collective mental health began in 1940 with the creation of the Harlem 
Sjuvenile justice speculated that delinquepecial Child Guidance Service Unit (HSCGSU). Psychiatrist Max Winsor spearheaded and administered this program. Lasting from 1940-1942, Winsor's program mobile child guidance team available to three junior high schools and, by 1941, a kindergarten in neighborhoods with the highest juvenile delinquency rates. Through 1941-1942's Joint Kindergarten Project, P.S. 194, an elementary school with a predominantly black student population, received the most intensive and collaborative services the HSCGSU offered any school, making it a central base of operations in the liberal effort to eliminate the racial slippage in productive power's metropolitan expansion.

This Joint Kindergarten Project was the HSCGSU's most concerted effort to extend productive power into New York's African American communities (Kirkpatrick, 1990; Ackerly, 1973). Racial liberals in juvenile justice speculated that delinquency rates would tumble if authorities could somehow identify, track, and treat potential delinquents before they had even committed a crime. Preferably, they hoped to identify and begin psychiatric interventions with these troubled youngsters in early childhood when, according to child guidance experts, humans were most therapeutically reachable. Kindergarten was the first public institution all children were obligated to enter. Viola W. Bernard (1942), the psychiatric resident who ran the kindergarten program, (1942), recognized that P.S. 194 thus offered the state its first real opportunity to collect data on a potential delinquent's "total needs, assets, and liabilities as early as possible in his or her school experience." ${ }^{2}$ Working with every kindergartener, Bernard's team of psychologists, case workers, and classroom aids conducted psychological tests and classroom observations, interviewed families, and even made home visits (Bernard, 1998). Although the program lasted less than two years, Bernard hoped that the data could be securely maintained in a central registry and be made available to the police, the courts, and other agencies interested in a specific child (Robison, 1960, pp 47-54). Armed with this data, Bernard expected that authorities could tailor educational and clinical services for the children identified as at greatest risk for juvenile delinquency. It was hoped that such personalized scrutiny could help each student to learn to control his or her impulses, mood, and behavior-primary goals within regimes of productive power (Bernard, 1942).

\section{The Harlem project, 1943-1945: forging a community of mental health}

The Harlem Special Child Guidance Service Unit lapsed in 1942, but its successor program-the Harlem Project--attempted to do something even more ambitious in the pursuit of productive power's expansion: transform Harlem into an emotionally healthy community by making school the center of this healthier Harlem. As Edward Ramsden and Matthew Smith (2017) have demonstrated, psychological experts and urban reformers have long argued that America's cities were breeding grounds for mental illness and juvenile delinquency. Starting in the 1920s, advocates of what became known as slum clearance and urban renewal theorized that better urban planning and the destruction of older housing stock could eliminate the environmental conditions that gave rise to misbehavior. A small surge in black youth crime had stimulated New York's racial liberals to make an attempt at socially engineering an emotionally healthier Harlem. The sensationalistic local news dailies reported the small surge as a major crime wave that had hit this predominantly black enclave of the city in November 1941 (Brandt, 1996; Kelley, 2009). Local racial liberals and civil rights activists took advantage of the panic the press had generated in the city, politicizing this alleged Harlem crime wave as further proof that Harlem required better crime prevention and mental health services and an end to racial inequality. In response to the panic over the crime wave, they formed a new civil rights organization, the City-Wide Citizens Committee for Harlem (CWCCH), in late 1941. In some sense, the $\mathrm{CWCCH}$ served as a kind of think-tank for local housing reformers, activists, politicians, academics, mental health experts, and public servants committed to ending crime, poverty, and socioeconomic disparities in Harlem. They imagined new policy solutions. One of the new policy solutions to emerge out of a $\mathrm{CWCCH}$ committee was the Harlem Project (Markowitz and Rosner, 2000).

Initiated in June 1943, the Harlem Project was a three-year experiment that the charitable New York Foundation had funded within New York's public school system (Markowitz and Rosner, 2000, p 13). Administered by many of the same judges, psychiatrists, educators, and mental health experts who created the HSCGSU, the Harlem Project aimed to transform three Harlem public schools (Junior High School 120, Junior High School 161, P.S. 10) with high child arrest rates into all-day community centers. The Project was rooted in two basic child guidance principles: first, that mental illness was responsible for most juvenile delinquency; and second, that "inadequate families" were chiefly responsible for causing the emotional distress that delinquents experienced (Harlem Project, 1949, p 39). As Matthew Smith (2016) noted, the child guidance movement was heavily influenced by psychoanalytic theory, placing any environmental blame for psychological problems squarely on the shoulders of the parents "rather than on broader social factors." The Harlem Project leaders never claimed or even intimated that racial biology had transformed Harlem into a den of bad parenting. Rather, according to Daryl Michael Scott (1997), racial progressives had argued as early as the 1910s that forces of racial and socioeconomic inequality made it that much harder for working-poor black families to promote the mental health of their children and serve as agents of personal growth and emotional stability. The well-meaning but condescending Harlem Project researchers and managers agreed with that assessment, claiming that "pervasive economic and social evils as result from segregation and prejudice" (Harlem Project, 1949, p 136) made it highly unlikely that Harlem's poorest black households would be the kinds of spaces that fostered self-control and healthy adjustment. The ease with which the Harlem Project Research Committee's members latched onto the explanation that poverty made it difficult to adequately parent was certainly a product of the unexamined class assumptions underlying both liberalism and most psychological theory. They had normalized the financial stability, educational attainment, and parenting philosophies of middle-class parents as somehow essential to the promotion of optimal human growth--a problem that marred much early 20th century childrearing literature (Stearns, 2004). So rather than oppose the longstanding pathologization of the working-poor black family, racial liberals reinforced this trope, claiming to offer a way to neutralize the psychological damage wrought by Harlem's alleged glut of bad parents.

In hopes of preventing local children from becoming delinquents, the Project aimed to redirect the locus of their emotional maturation away from emotionally damaging homes and into the school as the community's new center. The Harlem Project leaders expected that the desired changes in the curriculum, staffing, and administration of their three target schools would transform those buildings into therapeutic environments. Diagnostic and therapeutic services were made more readily available, mental health experts were regularly on site, teachers were given lessons in child psychology, and the Project clinicians and case workers were urged to serve as the students' parental substitutes. The Project leaders even hoped that schools could stay open all day and all through the summer, providing recreation, athletics, 
meals, mental hygiene, role modeling, and medical services. The idea was that the less time a child spent at home with their parents and the longer he or she spent at school with their parental substitutes, the odds of preserving any emotional breakthrough achieved there would increase. Essentially, the Project attempted to socially engineer an emotionally healthier Harlem and promote productive power by transforming its schools into spaces capable of producing self-possessed citizens less susceptible to the lure of crime. (Harlem Project, 1949; Board of Education, 1947-). By 1944 however, it had become obvious that both entrenched racial prejudice within the largely white faculty and wartime budgetary cutbacks had derailed the Project, preventing those three schools from ever serving as all-day, year-long community centers churning out law-abiding, well-adjusted Harlemites (Wittenberg, 1944; Harlem Project, 1949).

These liberal attempts to track and prevent juvenile delinquency did not aim to substantially alter Harlem's socioeconomic structure. None of those school programs instituted between 1940 and 1945 were accompanied by concomitant efforts to reduce the poverty, housing discrimination, chronic overcrowding, price gouging, decaying infrastructure, hiring discrimination, police brutality, and gang activity that had plagued Central Harlem since it had first been redlined by banks. The Harlem Project's Report (1949) did recognize that the mental health problems across 110th Street were in some ways the product of the inequalities and injustices that many of its black residents had been forced to endure. Ultimately though, the racial liberals who penned this final report believed that, barring wholesale structural change, the best they could do was to help at least some individual children avoid making big mistakes in life by becoming more emotionally secure and stable.

That is why the Project encouraged its staff, clinicians, and teachers to form intense emotional bonds with select students, especially girls, offering them the attention, nurture, and support they supposedly did not get at home. While the Project could not alter the relationship between African Americans and American society, they could create new relationships between some African American children and professional adult mentors that possessed a psychodynamic understanding of a developing child's psychological need for unconditional love and warmth. According to the tenets of child guidance theory, selfhood did not develop in isolation. Instead, the human self was a social product, forged in childhood either through a relationship with the child's primary caregiver or some other close guardian. The Harlem Project's Research Committee argued that their female staff had succeeded in becoming "mother substitutes" for some of the so-called "unmanageable girls"-the gender-appropriate term then for female students with disciplinary problems. In line with child guidance thinking, the Report credited these relationships with producing healthier selves for some of the girls. Some of them responded well to therapy and adjusted much better to school. According to the liberals' own assessment at least, the Project seemed to have found one way to increase productive power in Harlem (Harlem Project, 1949, p 88, p 90, p 91).

Nevertheless, the Harlem Project's final report (1949) struck a decidedly less celebratory tone when it assessed its relative success with the main target of its anti-delinquency efforts: the young men who made up the bulk of child arrests. The Research Committee claimed that a relationship with a school mentor at school, most of whom were women, did not do enough to change the affect and behavior of troubled African American boys in Central Harlem. It reached the conclusion that essential gender differences explained the disparate results between boys and girls. Falling back on well-worn, Victorian-era gender assumptions about a woman's proper place, the committee intimated that a woman's personality was largely built at home through one-on- one attention paid by a female role model. The Project worked well with girls, the committee contended, because the schools could approximate the conditions necessary for that sort of domestic relationship in a private office with a female teacher or case worker. Drawing upon traditional gender assumptions once again, the same writers claimed that the boys of Junior High School 120 were far less likely to have their emotional needs met in the confines of an office. As males they were drawn to Harlem's streets and the masculine temptations of gangs, petty crime, rowdy games, property destruction, fights and violence. Without enough after-school activities or male role models at school, there was little the Project leaders believed that they could do in Harlem for the most troubled young men living across 110th Street. But they imagined they might have better luck finding a more suitable therapeutic environment in the Catskill Mountains.

\section{The Wiltwyck school for boys and Claude Brown's sense of self, 1948-1965}

Claude Brown (1965) dedicated his memoir to: "The late Eleanor Roosevelt, who founded the Wiltwyck School for Boys. And to the WILTWYCK SCHOOL, which is still finding Claude Browns." In 1937, the Wiltwyck School for Boys began as a summer camp that New York's Protestant Episcopal Mission Society ran in Esopus, a small town in New York's bucolic Catskills. Eventually it became a year-round private reform school for pre-teen boys from New York City. In 1942, the facility stood on the brink of closure. But it was one of the few private facilities that would accept black male delinquents at a moment when arrests of young men were on the rise, space in private boys' reformatories was limited, and children's care providers could still discriminate on the basis of race. With arrest rates lower for young women, space was less limited in private facilities for women, and beds more available for black women in the House of the Good Shepherd and other private providers (Hicks, 2010). As Children's Court justices with a racial justice bent, Justine Wise Polier and African American judges Jane Bolin and Herbert T. Delany regularly assigned young black men from Harlem to Wiltwyck. Determined to keep the school open, Polier contacted some of her closest political allies including Eleanor Roosevelt (Polier's family friend and the First Lady of the United States) and many of the racial liberals and philanthropists involved with the Harlem Project (Bernstein, 2001, p 55). Pooling their funds, these racial liberals and their allies took over the administration of the Wiltwyck School. Under their watch it became a residential treatment center (RTC). Originating in World War II, an RTC was a facility that, according to historian Deborah Doroshow (2016), treated its clients as "emotionally disturbed" children requiring psychotherapy rather than as delinquents in need of correction. RTCs were supposed to offer psychiatric care, counseling, case work, and staff informed by child psychology. New York liberals in the juvenile justice system held out hope that Wiltwyck the rural residential treatment center, located far from the city's temptations, might offer the best way to put Harlem's troubled young men on the path to mental health. And in 1948, one of those young men was Claude Brown.

At 11 years of age, Claude Brown-known to his family as "Sonny"-was sent to Wiltwyck following his arrest for robbing a store on Broadway and $147^{\text {th }}$ Street in Harlem. In Children's Court the next day, Jane C. Bolin was the presiding judge. A sponsor of the Harlem Project and a member of the Wiltwyck School's board of directors once it had made the transition to RTC, Bolin initially assigned him to the Youth House on East 12th Street-a local juvenile detention center--while awaiting adjudication. Constantly in trouble, Brown had already been expelled from three schools at age eight and even sent to Bellevue 
Psychopathic Hospital for a psychiatric evaluation after he was "falsely accused of trying to push a boy out of a five-story window" (Brown, 1965, p 22). On January 5, 1949 Brown returned to court for his placement hearing and Bolin said "she was going to place me in some kind of school for boys..." He initially thought he was bound for the Warwick State Training School, a notorious state-run reform school. Instead, he was transported by train to Wiltwyck on March 4, 1949 (Brown, 1965, p 64, p 66).

It was there he met Ernst Papanek, the figure that Brown claimed had put him on the path towards the emotional health and stability racial liberals had been seeking to promote in Harlem. An Austrian immigrant, Ernst Papanek was a psychiatric social worker the Wiltwyck board had chosen as its new executive director the same year Brown became a resident. Papanek had joined the school just as Wiltwyck's Board was making a concerted effort to transform it into an RTC. Papanek (1951) pushed the staff to be more mindful of their charges' emotional development and he led by example. Brown enjoyed talking with him about "something really bothering me. Most of the time, I never told him what was really bothering me, but we would always talk about something. And regardless of what we talked about, it always made me feel better" (Brown, 1965, p 121). In these sessions, Papanek listened to Brown, praised him, encouraged him, gave him life advice, and counseled him on different strategies for getting along with his family (Brown, 1965, p 121, p 123). He was benefiting from the care and guidance of this social worker, developing such a strong attachment to him that Brown recalled that: "...he was all I had then...He was the first person I ever wanted to do anything for" (Brown, 1965, p 123). After Brown's release from Wiltwyck, he got in trouble for theft again and was sent to the Warwick State Training School. Nonetheless, Brown never blamed Papanek or Wiltwyck. He believed that he had failed them, indicating in his memoir that he sensed that he had not yet become the type of person that could stay out of juvenile detention.

One of the least-studied aspects of Brown's memoir is the young author's awareness of something akin to what philosopher Ian Hacking calls "historical ontology," the recognition that different times and places produce different kinds of selves or subjectivities for individuals to inhabit and practice. Throughout "Manchild", Brown demonstrates a fairly uncommon epistemological sense that American culture offered a number of "possible ways to be a person," of imagining how one's individual self is fundamentally organized or constituted (Hacking, 2002, p 2, pp 3-4, pp 22-23). He partially attributed his successful transition into adulthood to his discovery that the modern language of psychology provided the best way to make sense of his interior self.

Through his association with the Wiltwyck School the author learned that his interior landscape was a hidden world of drives, fears, emotions, anxieties, stages of development, and complexes that motivated his behavior without his conscious awareness. Brown credited Papanek with helping him to both gain this modern insight into human interiority. Brown "used to think the cat was a little crazy at first" because the language of psychology and child guidance was so new to him. But eventually he began to think that Papanek "had the ability to see everybody as they really are-just people, no more and no less. Also he saw children as people, little young people with individuality, not as some separate group of beings called children, dominated by the so-called adult world" (Brown, 1965, p 120). By the time the courts remanded him to the Warwick State Training School in his teenage years, Brown began to see that some individuals-such as Papanek-"seemed to have a whole lot of control over life and knew what he was going to do and what he wasn't going to do" (Brown, 1965, p 151). Brown thought of Papanek as modeling a specific type of individual or mode of being, one that featured psychological insight into oneself as a key component of its assemblage. At the RTC he became determined to become that sort of person, to achieve that kind of self-awareness and mastery of one's own instincts and emotions and to achieve it on the streets of Harlem no less. In Foucauldian terms, he was looking to become an agent for the expansion of productive power into Harlem.

Nevertheless, Brown found it difficult to maintain this emotional health in postwar Central Harlem. Remarkably, Brown learned something that many academics had not yet embraced in 1965: different types of selves or subject positions are difficult or even impossible to implement if a given culture or social system does not recognize, nurture, and reinforce those subjectivities (Hacking, 2002, pp 22-23). Throughout the memoir, Brown intuitively grasped the proposition that subjectivity was conditional, fluid, and situational. An individual could inhabit a particular mode of being but only in certain environments. Once he was released back to his family in Harlem after two and a half years, he felt that: "I had changed...I was moving away from things. There was no place for me. I felt lonelier in Harlem that I'd felt when I first went to Wiltwyck" (Brown, 1965, p 103). At Wiltwyck he had begun to develop a different kind of subjectivity, one that was more reflective and less volatile. Yet at home in Central Harlem, he found it difficult to sustain that healthier kind of self. In Harlem, he found that his parents did not understand or meet his emotional needs. The friends and the environment of the "the streets" (Brown, 1965, p 415) only seemed to push him to be the kind of person who had previously ended up in court. Among his old friends, he slipped into bad habits. He resumed skipping school, fighting, stealing, and smoking marijuana. "I had a feeling that something kind of bad was in store for me out on the streets" and "I longed to get back into Wiltwyck" despite-at 13 years of age-being too old for re-admittance (Brown, 1965, p 119).

In one sense, Brown's narrative seemed to confirm what the Harlem Project's racial liberals had suspected would happen to Harlem's troubled male youth when released from a therapeutic environment. Combined together, the lure of mischief in Harlem's public spaces and an inadequate family life were supposed to keep someone such as Brown from maintaining the developmental gains made in Esopus, New York. According to Brown, "I used to feel that I belonged on the Harlem streets...I always thought of Harlem as home, but I never thought of Harlem as being in the house. To me, home was the streets. I suppose there were many people who felt that way. If home was so miserable, the street was the place to be" (Brown, 1965, p 415). Similar to the Harlem Project writers, Brown partly blamed his parents for his delinquency. According to Brown, they were "old-fashioned and countryfied" transplants from rural, Depression-era South Carolina "who still have most of the Southern ways" (Brown, 1965, p 301). They did not model behavior for their children, relying instead on instilling fear and shame through aggression, insults, and corporal punishment. "Mama and Dad..[t]hey were trying to bring that down-home life up to Harlem. They had done it. But it just wasn't working" (Brown, 1965, pp 282-283). Without any consideration of child psychology, they did not show much affection or seek to understand their children's feelings. He deemed them ill-suited to help him and his brother adjust to modern, urban life. For Brown, his family became a burden he just wanted to escape. Harlem's well-traversed thoroughfareswith their temptations of violence, sex, theft, and drugs--were his outlet. Racial liberals would have expected as much. Slum family dynamics and the lure of urban excitement would sabotage any therapeutic successes made with any young man recently released from an RTC. 
Nevertheless, Brown and New York's racial liberals diverged as to whether therapeutic aftercare could undo the power of poor parenting and Harlem street-life. Wiltwyck's continued existence hinged on the directors' conviction that followup care with its former students could prevent recidivism. In the 1940s, former residents were encouraged to meet with a case worker at Wiltwyck's Harlem office on 125th street. After his release, Brown visited the office when he was in emotional distress, fearing that he would get in trouble with the law. At one visit in 1950, Papanek "seemed determined to force me to make it out on the street." (Brown, 1965, p 121) Even as Brown got involved in selling drugs and spent time in juvenile detention over the course of the next 3 years, Papanek told his staff in 1953 that Brown was going to "make out just great" (Brown, 1965, 167). Despite Papanek's confidence, an internal study Wiltwyck conducted the following year discovered that the recidivism rate among its graduates stood at $50 \%$ since the school opened. To change that rate, Wiltwyck's liberal directors believed that Wiltwyck needed to provide much more followup care-especially in the city. Between 1954 and 1962, Wiltwyck opened two half-way house facilities in New York City, one in St. Albans, Queens and one on $18^{\text {th }}$ Street named for champion boxer and former Wiltwyck student Floyd Patterson (Doyle, 2015). Aftercare was now far more intense and psychiatric in orientation. Brown never offered his opinion on Witwyck's new continuous care program or what he thought of its aftercare facilities. Instead his memoir provides evidence that he was nowhere as bullish on the idea that reintegration back into Harlem ought to be the aim of therapy and followup care.

Brown came to a different conclusion, one that the liberals at Wiltwyck were unwilling to completely accept. Throughout "Manchild in the Promised Land" Brown indicated that emotional health would be difficult or even impossible to produce in Harlem. Taking stock of his neighborhood, especially the cultural assumptions his Southern-born family members and neighbors shared about human selfhood, he became convinced that a healthy psychological self could not be adequately grown and sustained in Central Harlem. Returning from Wiltwyck he claimed that: "I didn't feel a part of Harlem any more...After a while, I thought it might be a good idea for me to move out of the neighborhood and see some other sides of life" (Brown, 1965, p 176). Describing working-poor Harlem of the 1950s as a culture rooted in pre-modern folk ideas transplanted from traditions of conjure, rural Southern small-town life, and evangelical Christianity, Brown found his neighborhood ideologically and culturally ill-prepared to sustain the type of self he was trying to cultivate. Brown observed that: "...everybody in Harlem needed something. Some people needed religion. The junkies needed drugs. Some people needed to get drunk on Saturday night and raise hell. A lot of people needed the numbers. Me, I needed to get the hell out of Harlem" (Brown, 1965, p 203). He did just that.

In the memoir, Brown became the kind of emotionally stable, law-abiding citizen deemed essential to regimes of productive power-but only once he moved out of Harlem. Finding support for his new self in Wiltwyck's downtown Manhattan offices, he moved to Greenwich Village, settling down in a "little loft room down on Cooper Square" (Brown, 1965, p 177). He left the underground economy behind and began a new life in an environment that left him with less anxiety and conflicted feelings. "I was afraid of what Harlem could bring out in a person. When I decided to move, I was trying to get away from the fear" (Brown, 1965, p 414). He found steady work, graduated night school, played jazz piano, read books, listened to poetry readings, and began to interact with other young people who understood interiority in the same modern psychological terms he had picked up at Wiltwyck. He felt that he had adapted to downtown life so well that he told one acquaintance that he "blended in with the furniture" (Brown, 1965, p 348).

\section{"Why the Ghetto Must Go": manchild in a post-apocalyptic promised land}

When "Manchild in the Promised Land" was published in 1965, leftist critics vilified Brown's book, claiming that he blamed Harlem's black community rather than racism for the problems he experienced. They immediately panned Brown for failing to see how structural forces beyond his neighbors' and family's control were really what set African Americans his age off on the path of crime, mental illness, or drug addiction. White voices from the left, including "Village Voice" jazz reviewer Nat Hentoff, anarchist and education critic Paul Goodman, and novelist and socialist Warren Miller, noted that Brown's book made no mention of the civil rights movement, neglected to explore how African Americans could collectively struggle to improve their lot, and offered individual self-discovery and flight from segregated black communities as the only solution to the 1960s' urban crisis. These critics regarded his analysis of his subjectivity, existential angst, psychological turmoil, and relationship with the Wiltwyck School as pointless navel-gazing that drew attention away from the larger, more practical issues of institutional racism, housing segregation, wealth inequality, and governmental neglect of black communities. (Rotella, 1998, pp 293-310, Tochterman, 2017, pp 108-109)

While there is merit to those criticisms, much of the vitriol directed at Brown had just as much to do with the book's timing. "Manchild" appeared at a moment when, according to historians Laura Briggs (2002) and Mical Raz (2013), liberal and neoconservative sociologists, psychologists, and other academicians argued that slum-dwelling had psychologically damaged the poor, especially in predominantly black neighborhoods. The year "Manchild" was published, two landmarks in urban black pathology literature were also released: Harlem psychologist Kennth B. Clark's "Dark Ghetto" and sociologist Daniel Patrick Moynihan's infamous report for the US Department of Labor, "The Negro Family: A Case for National Action". Both Clark's "Dark Ghetto" and Moynihan's report presented inner-city black enclaves as dens of poverty and mental pathology. And both authors traced these developments to an unhealthy black family structure characterized by domineering matriarchs and emotionally weak fathers emasculated by racial discrimination (Herman, 1995, pp 192-193; Martin, 2013, pp 21-38; Scott, 1997, pp $150-159)$. In the works of these and other social scientists including Frank Riessman, Nathan Glazer, and Oscar Lewis, theories touting the existence of a "culture of poverty" and "cultural deprivation" in slums presented the nonwhite poor as the practitioners of an inferior lifestyle and family dynamic that had doomed them to a future of inescapable poverty (Raz, 2013; Scott, 1997).

Brown's critics and other radical intellectuals vehemently attacked the proposition that poverty was a psychologically damaging culture rather than an economic condition, arguing that the concept could be used to justify political inaction in the battles against poverty and racial injustice. In the aftermath of the 1965 Watts Rebellion, policymakers both in California and in Pres. Lyndon B. Johnson's administration framed this urban uprising as a symptom of family instability and psychological decline in black ghettos, citing the Moynihan report and similar works as support (Herman, 1995, pp 206-207; Scott, 1997, pp 156-159) Psychologist William Ryan (1971) argued that the official reliance on facile cultural and psychological explanations for the rioting in Los Angeles "blamed the victims" and depoliticized the riots, ignoring the Watts residents' legitimate 
grievances against police brutality, housing discrimination, and inadequate social services. Ryan recognized that if slum-life was psychologically damaging and the culture of the black poor was the culprit, then legislators had no reason to fight economic and racial inequality. In the fight against both the culture of poverty thesis and the urban disinvestment it justified, scholars and activists pointed to the existence of thriving communities in the midst of poverty. In sociology, Herbert Gans' (1962) classic "Urban Villagers", drawing upon field work he had begun in 1957 among working-class Italian-Americans in Boston's West End, argued that emotionally healthy communities could form within slums. (Ramsden and Smith, 2017, pp 15-17) Poet Amiri Baraka and other black cultural nationalists even pointed to Harlem and the stabilizing presence of the Nation of Islam's Temple Number Seven and his own Black Arts Movement's lifestyle entrepreneurs as proof that Harlem was not a uniform den of pathology. (Joseph, 2006) Some of these leftist intellectuals and activists branded any claim that urban ghettos were rife with bad behavior and psychological damage as politically irresponsible and potentially "racist." (Scott, 1997, pp 177-183) Given that Brown's account of his own struggle depicted the Second Great Black Migration's Southern black transplants as rural rubes who failed to adapt to Northern urban life, critics assailed his work with the same vitriol they later reserved for the Moynihan report and, the next year, anthropologist Oscar Lewis's characterization of the badly behaved and seemingly irredeemable Boricuan denizens of San Juan's barrios and Manhattan's slums in "La Vida: A Puerto Rican Family in the Culture of Poverty" (Tochterman, 2017, pp 123-124; Briggs, 2002, p 178).

Nevertheless, some of the racial liberals who supported the theory that slum culture was deficient and psychologically harmful did not write off Harlem's ghetto denizens as therapeutically hopeless. They held out hope that psychiatry still held the key to break the cycle of poverty and enable some Harlemites to live emotionally healthy lives even in the midst of poverty. From 1960 to 1967, Wiltwyck psychiatrist Salvador Minuchin and his colleagues relied upon the new modality of family therapy to help recovering delinquents maintain their therapeutic gains in aftercare. (Weinstein, 2013) In "Families of the Slums", Minuchin (1967) argued that it was possible to change a slum family's dysfunctional family dynamics so that a poor family's home could become an environment capable of sustaining healthy personalities. "Families of the Slum" made it clear that the old liberal vision of expanding productive power within Harlem's African American neighborhoods could still be realized, one individual family at a time.

Brown however expressed skepticism that Harlem could either be redeemed or at least become a site where some lost souls could be saved. Instead he called for the destruction of ghettos, a position shared by other African American intellectuals and activists. One of these like-minded compatriots was novelist James Baldwin, a fellow Harlem native who had written one of the promotional blurbs supporting Brown's memoir. Between 1948 and 1966, Baldwin's fiction and his political essays decried Harlem and black urban ghettos as sociologically unique environments that had psychologically harmed their residents in ways that ethnic white immigrant enclaves such as Manhattan's Hell's Kitchen or the Lower East Side never had. His essays reveal a Harlem filled with "self-loathing...madness...frustration and bitterness." (Baldwin, 1962, pp 56-63). Yet unlike other authors in the urban pathology vein, Baldwin did not claim that flaws within black culture were to blame for the damage Harlem had caused the human psyche. Instead, Baldwin consistently recognized predominantly black slums and the mental health risks they carried as the product of years of racial discrimination in housing, employment, law enforcement, health, and education. In contrast to white ethnics who could leave their neighborhoods, most African Americans could not escape Harlem. Systemic racism in the credit, mortgage, and housing markets made sure of that. (Baldwin, 1962, 1963, 1985; Scott, 1997, p 165) In Baldwin's view, Harlem was a racially segregated and unequal place and its residents little more than hostages. Efforts to improve Harlem through urban renewal would be inconsequential and doomed to failure as a segregated slum's very existence was inhumane and antidemocratic.

In particular, Baldwin decried New York's ongoing efforts to rehabilitate Harlem through the destruction of its brownstone tenements and their replacement with cheap, low-income, public housing. (Tochterman, 2017, pp 83-84). In Baldwin's view, one shared by housing reformers such as Jane Jacobs (1961) in her landmark "The Death and Life of Great American Cities", urban renewal had done nothing to change Harlemites' life outcomes, promote economic opportunity, or ameliorate social injustice. New York's housing officials did not move the black poor out of Harlem. Instead, by locating the new public housing units in Harlem, urban renewal continued to concentrate the black poor within the same space they had inhabited before, sending African Americans the message that "they are living there because white people do not think they are good enough to live anywhere else." (Baldwin, 1962, p 65)

In an oft-anthologized 1960 "Esquire" article (1962, p 65) entitled "Fifth Avenue, Uptown," Baldwin wrote that: "A ghetto can be improved in only one way: out of existence." Sterling Tucker (1968, p 23), director of Washington D.C.'s Urban League, concurred, arguing that: "If it is to rid itself of the problems of the ghetto forever, if its cities are to survive, America must eliminate the ghetto and the ghetto mentality." African American ghettos were inherently unjust living spaces that were frankly beyond redemption, a sentiment Brown also evinced in his televised conversation with Podhoretz.

While Brown's critics were correct in their assertion that he never addressed the racism and socioeconomic forces that had made Harlem a "slum ghetto" the way that Baldwin or Tucker had, Brown did not simply blame his parents and their generation for Harlem's status as slum. Instead, he tried to convey that rural Southern transplants had arrived in a Harlem that was already unable to support their psychological health and successful citizenship. In "Manchild", Harlem appears as less a promised land than it does a wasteland, "... a dirty, stinky, uncared-for closetsize section of a great city" (Brown, 1965, p 8). Brown presents the Central Harlem in which he grew up in an almost nondescript fashion. It appears as little more than a ruinous void in which the family and friends of his youth play out their unmoored existence. Reviewers including Goodman, Podhoretz, and Hentoff interpreted the author's relative inattention to the Harlem environment as a function of the text's apparent message that individuals, culture, and psychology, not social forces or circumstances, had produced the slum's problems (Rotella, 1998).

Consequently, Podhoretz was caught off-guard when, in the midst of their exchange on public television, Brown indicated that Harlem--rather than the population that dwelled there--was beyond saving. Given Brown's use of psychological jargon and his criticisms of the habits, affect, and attitudes of the people in "Manchild", readers such as Podhoretz expected to write-off Harlem's residents, not Harlem itself. Yet, when read in light of Brown's conversation with Podhoretz, the memoir reveals Brown's understanding of Harlem as a space. Because Brown offered very little description in the way of what his neighborhood in Harlem even looked like or what resources or amenities it possessed, it is difficult for readers to determine what it lacked. Yet once Brown narrates his escape into Greenwich Village and actively presents what it had to offer him, it becomes clear that 
Harlem lacked jobs, legal opportunities for advancement, affordable amenities, social capital, services, and furnished living spaces. In that downtown environment he found material support for the kind of selfhood he had been looking to cultivate since his encounters with Papanek and Wiltwyck. In his estimation, Harlem was not equipped to help him to do that. And like Baldwin and Tucker, he did not think it ever could. Consequently, it was not worth retaining. Harlem was better off burnt to the ground.

\section{Conclusion}

In their televised 1965 conversation, Norman Podhoretz pressed Claude Brown further about what he meant when he suggested that burning Harlem and other ghettos would be "pretty nice":

Brown: It would be a great idea.

Podhoretz: To burn Harlem to the ground?

Brown: Yes, to burn Harlem to the ground and rebuild it.

Podhoretz: Well not really burn it. But bulldoze it or rebuild it.

Brown: Just demolish it. Whichever you prefer. (Podhoretz, Brown, 1965)

As both this exchange and his own "Manchild in the Promised Land" demonstrate, Brown was just as interested in Harlem's reclamation as the racial liberals of the Special Harlem Child Guidance Service Unit, the Harlem Project, and the Wiltwyck School for Boys. Unlike them however, Brown conceived of Harlem's reclamation as something entirely separate from the reclamation of the individual Harlemites who inhabited it. In answer to juvenile delinquency in Harlem, liberal psychiatrists, judges, educators, and other health professionals forged therapeutic solutions designed to alter individual African Americans and ultimately change the social landscape of Harlem.

To Brown, Harlem and other predominantly black urban spaces were not environments that could be expected to support the material needs of those undergoing therapeutic transformations. He recognized that the psychologically health mode of selfhood that he wanted for himself and that racial liberals wanted for Harlem's troubled black youth could only be forged in living spaces that offered good jobs, services, social capital, and supportive institutions. Brown and others like him could not be expected to change in Harlem unless Harlem changed first. Brown and other progressive black thinkers recognized that targeted social reforms would not fix Harlem or reduce the racial slippage in productive power's expansion. A ghetto was an inherently flawed space-the product of racial segregation, discrimination and neglect. It could not be salvaged and reformed into the kind of place where psychotherapy could work wonders with troubled youth. For Brown, a far more human solution was the outright destruction of segregated living spaces and their replacement with something far healthier and more supportive of individual emotional health.

Brown seemed to grasp that liberal attempts to rehabilitate troubled African Americans were weakened by the absence of efforts to "rebuild" Harlem. The program directors of the SHCGSU, the Harlem Project, and Wiltwyck did recognize that changes in environment aided the therapeutic process; otherwise they would not have tried turning schools into community centers, sending youth offenders to the mountains, or conducting therapy with delinquents' families. Yet they only identified the family as the environment in need of alterations. Such programs were stymied by a liberal confidence that individual therapeutic solutions to complex problems such as crime could be effective without serious efforts to either remake the spaces where crime took place or to permanently resettle recovering delinquents in stable, adequately resourced living spaces. Their faith in human will flew in the face of what Brown had learned about the self's contingent nature. As Brown and even some of his leftist critics understood, America's system of segregated living spaces had to end before the social problems that system generated could be adequately addressed.

In 1968 the Urban League's Sterling Tucker advocated that most racial inequalities and even individual health disparities in places such as Harlem could be solved by radical integrationism in housing. Where an individual lived in postwar America determined what sort of person he or she could become. Health, economic success, social stability and security came to those citizens with ready access to the most optimal resources. Increasingly, predominantly black urban spaces lacked those resources. Tucker advocated that government end racial segregation in housing and give African Americans of all income levels the freedom to live anywhere they wanted. According to Tucker, if the US was to become a place where more than just "a few Claude Browns touch a star," then: "What America must do is make it desirable for black people to be elsewhere" than Harlem (Tucker, 1968, p 5, p 26).

In some sense, through gentrification and the rise of the prison complex, America has made it desirable for the state to place black people-especially those in poverty or with mental illnessin spaces even less desirable than Harlem. Even after the Fair Housing Act of 1968 banning racial discrimination in housing, living space in the US remains segregated by race in the $21 \mathrm{st}$ Century. In the 2010s, people of color have become even likelier to occupy disinvested communities with high concentrations of poverty than in 1965 (Lipsitz, 2011). But, oddly enough, the location of those predominantly poor black spaces has changed. Through gentrification, Harlem's black denizens have been by displaced by a whiter, wealthier population-leading to increased homelessness and concentrations of black poverty and mental illness in housing projects within New York's outer boroughs. Owing to racial profiling, deinstitutionalization, and draconian drug laws, prisons in the post-civil rights era contain a disproportionate share of mentally ill African Americans. Neither the housing project nor the prison is the kind of environment Brown would have considered conducive to the mode of selfregulating selfhood he was trying to live (Metzl, 2009; Alexander, 2010).

As Harlem began to transform into a white professional commuter neighborhood in the early 2000s, journalist Sharifa Rhodes-Pitts (2011) learned firsthand that Harlem in the era of neoliberal redevelopment had become increasingly unable to meet the needs of the most vulnerable. Living in Harlem between 2002 and 2008, Rhodes-Pitts noted the rise of overpriced condominiums, trendy eateries, and coffee shops made possible by neoliberal tax incentives, subsidies, and other enticements that came at the expense of reduced government expenditures for health, social services, housing, and education. Within one of the hip new cafes, Rhodes-Pitts overheard a conversation between a recent white resident and his equally white and upwardly mobile guest. Awestruck by the gentrification, the guest said: "This is fabulous... Really you have to do something to get the word out. There need to be more people up here" (Rhodes-Pitts, 2011). By "people" the man meant the kind of allegedly self-managed citizens that 1940s' racial liberals hoped would proliferate in Harlem. Only the speaker's 'people' were not Harlem's native sons and daughters, they were privileged outsiders whose mode of selfhood required minimal social support from Harlem. These were mostly white individuals who had enough inherited wealth and social 
capital that they were able to work, network, invest, exercise, see a therapist, fill their prescriptions, and educate their children all outside of Harlem. Harlem could not adequately provide those things for black residents in Brown's lifetime. By the 2000s local government still did not adequately meet those needs, precisely because the new white residents were advantaged enough to have those needs met elsewhere. They just needed Harlem to provide luxurious spaces where they could eat and sleep. And as American policymakers increasingly seem incapable of responding to complex racial disparities with anything more than neoliberal solutions that expect individuals to change themselves without altering their circumstances, the US will continue to remain the sort of place where only "a few Claude Browns touch a star."

Received: 1 November 2017 Accepted: 15 January 2018

Published online: 06 February 2018

\section{Notes}

1 Here I am using the term productive in the sense intended by the late French intellectual Michel Foucault (2003, p 21, pp 48-52) and (1977, pp 20-24, pp 25-30; p 296, pp 298-303, p 305). Ably summarized here by Judith Butler (1993, p 22), this productive or "regulatory power produces the subjects it controls, that power is not imposed externally, but works as the regulatory and normative means by which subjects are formed." In a similar vein, on the role of modern families as decentralized agents of both the modern liberal state and the diffuse sort of state power achieved through individual self-management, see Donzelot (1979, pp 94-95) and Gordon (1991).

2 Viola W. Bernard was no ordinary psychiatric resident. A 1936 graduate of Cornell Medical College, Bernard had been a longtime friend of two vital HSCGSU administrators, Justine Wise Polier and psychiatrist Marion E. Kenworthy, one of the child guidance movement's founders. Their friend Bernard had already completed her first psychiatric residency at Westchester's Grasslands Hospital in 1938. She undertook a second residency at the New York State Psychiatric Institute in 1939 at the same time she had been accepted for training at the prestigious and exclusive New York Psychoanalytic Institute. In 1940, Max Winsor hired Bernard to serve as a part-time psychiatrist for the HSCGSU, convincing the American Board of Neurology and Psychiatry to accept her two years of part-time clinical work as the equivalent of a third-year of residency. In early 1942, Bernard, Winsor, and Polier joined the CWCCH. Bernard served on committees that Winsor and Polier headed, demonstrating alignment with their progressive racial politics. Shortly thereafter, Winsor gave Bernard the opportunity to shepherd the short-lived Joint Kindergarten Project, (Doyle, 2016, pp 68-69, p 86)

\section{References}

Ackerly S (1973) Interview with Viola W. Bernard. Columbia University, Health Sciences Library, Archives and Special Collections, Viola W. Bernard Papers, New York. (Hereafter VWB)

Alexander M (2010) The New Jim Crow: mass incarceration in the age of colorblindness. New Press, New York

Baldwin J (1962) Nobody knows my name: more notes of a native son. Delta, New York

Baldwin J (1963) The fire next time. Vintage, New York

Baldwin J (1985) The price of the ticket: collected nonfiction, 1948-1985. St. Martin's, New York

Bernard V (1942) Speech written for conference on October 8 1942. Health Sciences Library, Columbia University

Bernard V (1998) Some applications of psychoanalysis to social issues. Psychoanal Rev 85:139-170

Bernstein N (2001) The lost children of wilder: the epic struggle to change foster care. Vintage, New York

Board of Education of the City of New York. (1947-1948) Extended school services through the all-day neighborhood schools. Curric Bull 2:1-81

Brandt N (1996) Harlem at war: The black experience in WW II. Syracuse University Press, New York

Briggs L (2002) Reproducing empire: race, sex, science, and U.S. Imperialism in Puerto Rico. University of California Press, Berkeley

Brown C (1965) Manchild in the promised land. MacMillan, New York

Butler J (1993) Bodies that matter: on the discursive limits of sex. Routledge, New York

Donzelot J (1979) The policing of families. Random House, New York
Doroshow D (2016) Residential treatment and the invention of the emotionally disturbed child in twentieth-century America. Bull Hist Med 90(1):92-123

Doyle D (2015) Black celebrities, selfhood, and psychiatry in the civil rights era: the wiltwyck school for boys and the floyd patterson house. Social Hist Med 58:330-350

Doyle D (2016) Psychiatry and Racial Liberalism in Harlem, 1936-1968. University of Rochester Press, Rochester

Dwyer E (2005) Psychiatry and race during world war II. J Hist Med Allied Sci 61:117-143

Foucault M (1977) Discipline and punish: the birth of the prison. Pantheon, New York

Foucault M (2003) Abnormal: lectures at the college de France, 1974-1975. Picador, New York

Gans H (1962) The urban villagers: group and class in the life of Italian Americans. Free Press, New York

Garcia J (2012) Psychology comes to Harlem: rethinking the race question in twentieth-century America. Johns Hopkins University Press, Baltimore

Gordon C (1991) Governmental rationality: an introduction. In: Burchell G, Gordon C, Miller P (ed) The Foucault effect: studies in governmentality. University of Chicago Press, Chicago

Hacking I (2002) Historical ontology. Harvard University Press, Cambridge

Harlem Project Research Committee (1949) The role of the school in preventing and correcting maladjustment and delinquency: a study in three schools. New York Foundation, New York

Herman E (1995) The romance of American psychology: political culture in the age of experts. University of California Press, Berkeley

Herman E (2008) Kinship by design: a history of adoption in the modern United States. University of Chicago Press, Chicago

Hicks C (2010) Talk with you like a woman: African American women, justice, and reform in New York, 1890-1935. University of North Carolina Press, Chapel Hill

Horn M (1989) Before it's too late: the child guidance movement in the United States, 1922-1945. Temple University Press, Philadelphia

Jacobs J (1961) The death and life of great American cities. Vintage, New York

Jones K (1999) Taming the troublesome child: American families, child guidance, and the limits of psychiatric authority. Harvard University Press, Cambridge

Joseph P (2006) Waiting 'til the midnight hour: a narrative history of black power in America. Henry Holt, New York

Karolides N, Bald M, Sova D (1999) 100 banned books: censorship histories of world literature. Checkmark, New York

Kelley R (2009) Thelonious monk: the life and times of an American original. Free Press, New York

Kirkpatrick W (1990) Interview with Viola W. Bernard. VWB.

Lipsitz G (2011) How racism takes place. Temple University Press, Philadelphia

Markowitz G, Rosner D (2000) Children, race, and power: Kenneth and Mamie Clark's northside center. Routledge, New York

Martin D (2013) On the corner: African American intellectuals and the urban crisis. Harvard University Press, Cambridge, 2013

Mendes G (2015) Under the strain of color: Harlem's Lafargue clinic and the promise of an antiracist psychiatry. Cornell University Press, Ithaca

Metzl J (2009) The protest psychosis: how schizophrenia became a black disease. Beacon, Boston

Morris R (2008) The Miner's ear. Transition 98:96-115

Muhammad K (2010) The condemnation of blackness: race, crime, and the making of modern urban America. University of Harvard Press, Cambridge

Minuchin S (1967) Families of the slums: an exploration of their structure and treatment. Basic, New York

Papanek E (1951) Report of the executive director to the board of directors: September 1949 to June 1951. VWB.

Podhoretz N, Brown C (1965) Nobody wants to hear that nonsense in Harlem. New Repub 153:20

Polier J (1940) Letter to Hon. James Marshall. Radcliffe Institute for Advanced Study, Schlesinger Library, Justine Wise Polier Papers, Cambridge

Ramsden E, Smith M (2017) Remembering the West End: social science, mental health and the American urban environment, 1939-1968. Urban History 1-22. https://doi.org/10.1017/S0963926817000025

Raz M (2013) What's Wrong with the Poor? psychiatry, race, and the war on Poverty. University of North Carolina, Chapel Hill

Rhodes-Pitts S (2011) Harlem is nowhere: a journey to the Mecca of Black America. Little, Brown, New New York

Robison S (1960) Juvenile delinquency: its nature and control. Holt, New York

Rotella C (1998) October cities: the redevelopment of urban literature. University Press, Berkeley

Ryan W (1971) Blaming the victim. Vintage, New York

Scott D (1997) Contempt and pity: social policy and the image of the damaged blackpsyche, 1880-1996. University of North Carolina Press, Chapel Hill

Smith M (2016) A fine balance: individualism, society, and the prevention of mental illness in the United States, 1945-1968. Palgrave Commun 2:1-13 
Staub M (2011) Madness is civilization: when the diagnosis was social, 1948-1980. University of Chicago Press, Chicago

Stearns P (2004) Anxious parents: a history of modern childrearing in America. New York University Press, New York

Stoler A (2009) Along the Archival Grain: Epistemic Anxieties and Colonial Common Sense. Princeton University Press, Princeton

Summers M (2014) Diagnosing the ailments of black citizenship: african american physicians and the politics of mental illness, 1895-1940. In: Green L, McKiernan-Gonzalez J, Summers M (eds) Precarious prescriptions: contested histories of race and health in North America. University of Minnesota Press, Minneapolis

Tochterman B (2017) The dying city: postwar New York and the ideology of fear. University of North Carolina Press, Chapel Hill

Tucker S (1968) Why the Ghetto must go, pamphlet, Public Affairs Committee, New York

Ward G (2012) The black child-savers: racial democracy and juvenile justice. University of Chicago Press, Chicago

Weinstein D (2013) The pathological family: postwar America and the rise of family therapy. Cornell University Press, Ithaca

Wittenberg R (1944) Rethinking the clinic function in a public school setting. Am J Orthopsychiatry 14:725

\section{Data availability}

All data generated or analyzed during this study are included in this published article.

\section{Additional information}

Competing interests: The authors declare no competing financial interests.

Reprints and permission information is available online at http://www.nature.com/ reprints

Publisher's note: Springer Nature remains neutral with regard to jurisdictional claims in published maps and institutional affiliations.

\section{(c) (1)}

Open Access This article is licensed under a Creative Commons Attribution 4.0 International License, which permits use, sharing, adaptation, distribution and reproduction in any medium or format, as long as you give appropriate credit to the original author(s) and the source, provide a link to the Creative Commons license, and indicate if changes were made. The images or other third party material in this article are included in the article's Creative Commons license, unless indicated otherwise in a credit line to the material. If material is not included in the article's Creative Commons license and your intended use is not permitted by statutory regulation or exceeds the permitted use, you will need to obtain permission directly from the copyright holder. To view a copy of this license, visit http://creativecommons.org/ licenses/by/4.0/.

(C) The Author(s) 2018 